\title{
Pengaruh Paparan Pestisida Pada Masa Kehamilan Terhadap Kejadian Autisme
}

\author{
The Effect of Pesticide Exposure in Pregnancy to Incident Autism
}

\author{
Ghina Risky Juanda ${ }^{1 *}$ \\ ${ }^{1}$ Fakultas Kedokteran Universitas Lampung \\ J1. Prof. Dr. Ir. Sumantri Brojonegoro No. 1, Bandar Lampung, Lampung, Indonesia \\ Email : ghinariskyjuanda@gmail.com
}

\begin{abstract}
ABSTRAK
Pestisida merupakan suatu bahan kimia yang sering digunakan untuk mengendalikan/membasmi organisme pengganggu, hal ini sangat menguntungkan bagi hasil produksi pertanian. Namun, beberapa penelitian menyatakan bahwa penggunaan pestisida memiliki dampak negatif terutama bagi kesehatan pengguna pestisida baik itu petani maupun konsumen. Salah satu kelompok yang paling berisiko terhadap dampak pestisida adalah perempuan, hal ini disebabkan karena peran dari perempuan dalam sektor pertanian sangat besar. Paparan pestisida selama kehamilan dapat mempengaruhi perkembangan pada anak. Pestisida memiliki efek EDC (Endocrine Disruptor Chemical) atau memiliki sifat antitiroid, faktor yang dapat menyebabkan autisme. Beberapa jenis pestisida yang memiliki efek EDC antara lain 2,4-dichlorophenoxyacetic acid (2,4-D), mancozeb, acetochlor, aminotriazole, aminotrole, bromoxynil, pendamethalin, dan thiourea. Bahan-bahan ini dapat berkompetisi dengan reseptor hormon tiroid sehingga menyebabkan hormon tiroid tidak dapat berikatan dengan reseptor, kerja hormon tiroid dapat terinhibisi dan terjadilah kondisi hipotiroid. Penurunan kadar tiroid dapat menurunkan kemampuan pertumbuhan dari dendrit pada sel purkinje di cerebellum yang diperantarai oleh hormon tiroid. Hal tersebut dapat mempengaruhi neuroanatomi dan neurokemistri dari neurotransmitter pada otak sehingga dapat menyebabkan kondisi autisme. Anak dengan autisme dapat mengalami gangguan pada aktivitas sensorik, motorik yang repetitif dan keterbatasan minat atau kelebihan minat pada suatu hal tertentu.
\end{abstract}

Kata kunci: Autisme, Hipotiroid, Kehamilan, Pestisida

\begin{abstract}
Pesticides are chemical materials that used to control or eradicate insect, which is very beneficial for agricultural production. However, some studies declare that use of pesticides has a negative impact especially on health of users both farmers and consumers. One of the groups that most at risk to impact of pesticides is a women, because of the most participate women in agricultural sector. Exposure to pesticides during pregnancy can affect developmental disorders in children. Pesticides had an EDC (Endocrine Disruptor Chemical) effect or antithyroid properties, which are factors that cause autism. Several types of pesticides that had EDC effect are 2,4-dichlorophenoxyacetic acid (2,4D), mancozeb, acetochlor, aminotriazole, aminotrole, bromoxynil, pendamethalin, and thiourea. Materials can compete with thyroid hormone receptors and make thyroid hormones cannot bind to receptors or thyroid hormones can be inhibited and hypothyroid conditions can occur. Decreased of thyroid levels can reduce the growth ability of dendrites in purkinje cells in the cerebellum that mediated by thyroid hormones. This matter can effect neuroanatomy and neurochemistry of neurotransmitters in a brain, can lead autism. Children with autism had an experience disturbances in sensory activity, repetitive motoric skills and limited or excess interest in particular things.
\end{abstract}

Keyword: Autism, Hypothyroid, Pregnancy, Pesticides 


\section{Pendahuluan}

Pestisida adalah suatu bahan kimia maupun campuran beberapa bahan kimia yang sering digunakan untuk mengendalikan atau membasmi organisme pengganggu. Pestisida sering digunakan karena memiliki beberapa keuntungan, diantaranya melindungi tanaman dari serangan hama sehingga ketersediaan bahan pangan tercukupi dan dapat digunakan dalam pengendalian penyakit yang dibawa oleh beberapa vektor. Hama merupakan organisme target dari efek toksik yang dimiliki oleh pestisida, namun pada kenyataannya, sebagian besar bahan aktif yang digunakan tidak cukup spesifik toksisitasnya, sehingga memiliki dampak negatif terhadap kesehatan manusia (Costa,2008).

Setiap tahun diperkirakan jutaan orang yang terlibat di pertanian menderita keracunan akibat penggunaan pestisida. Berdasarkan data dari organisasi kesehatan dunia (WHO) dan program lingkungan persatuan bangsa-bangsa (UNEP) terdapat 1-5 juta kasus keracunan terjadi pada pekerja di sektor pertanian. Selain itu, masyarakat yang berada disekitar lokasi pertanian sangat berisiko terpapar pestisida baik melalui udara, tanah dan air yang tercemar, bahkan konsumen dari produk pertanian yang menggunakan pestisida berisiko terkontaminasi pestisida (Bambang, Onny \& Nur, 2013).

Salah satu kelompok yang paling berisiko terhadap dampak pestisida adalah perempuan, hal ini disebabkan karena peran dari perempuan dalam sektor pertanian sangat besar. Menurut data dari Badan Pangan Dunia di Perserikatan Bangsa-Bangsa (FAO) menunjukkan bahwa jumlah perempuan yang terlibat dalam sektor pertanian mengalami peningkatan dari tahun ke tahun. Pada tahun 1960 terdapat 7,43 juta pekerja perempuan dan meningkat hampir empat kali lipat pada tahun 2000 menjadi 20,82 juta. Pada tahun 2008 menurut data pertanian, di Indonesia 50,28\% dari total jumlah tenaga kerja di sektor pertanian adalah perempuan(Bambang, Onny \& Nur, 2013).

Beberapa penelitian di negara Asia menemukan bahwa perempuan adalah pekerja utama di sektor pertanian dan perkebunan, yang berhubungan langsung dengan penggunaan pestisida dalam pekerjaannya sehari-hari. Di Malaysia, keterlibatan perempuan dalam sektor pertanian hampir $80 \%$ dari 50.000 pekerja, dimana sebanyak 30.000 orang aktif sebagai penyemprot pestisida. Dengan banyaknya perempuan yang berperan di sektor pertanian dan terpapar pestisida secara langsung, mengakibatkan perempuan sangat berisiko mendapatkan gangguan kesehatan, mulai dari gangguan kesehatan secara umum maupun terhadap organ reproduksi yang juga akan sangat berpengaruh terhadap bayi yang dilahirkannya (Bretveld et al, 2006).

Paparan pestisida selama kehamilan dapat mempengaruhi gangguan perkembangan pada anak. Menurut data survey pada tahun 2016 menyebutkan bahwa beberapa anak dengan orang tua yang menggunakan pestisida dalam lahan pertanian di Desa Sumberejo (dimana desa tersebut tingkat penggunaan pestisidanya cukup tinggi dan intensif), dari 5 anak yang diteliti, sebanyak 60\% anak mengalami keterlambatan perkembangan dan $40 \%$ anak memiliki perkembangan yang unik. Beberapa ibu dari 5 anak tersebut tinggal satu mil dari lahan pertanian yang menggunakan pestisida jenis organofosfat. Penelitian lainnya menyebutkan bahwa ibu hamil yang terpapar organofosfat saat hamil $60 \%$ lebih berisiko anak yang dilahirkan mengalami gangguan spektrum autism (Whyatt et al, 2004).

Tujuan dari studi pustaka ini adalah untuk memaparkan bukti-bukti ilmiah bahwa adanya pengaruh dari paparan pestisida pada masa kehamilan terhadap kejadian autisme pada bayi yang dilahirkan.

\section{Pembahasan}

Pestisida adalah semua bahan kimia, serta bahan lain, termasuk jasad renik dan virus yang digunakan untuk memberantas tanaman dan hewan yang merusak pertanian, dan menumbuhkan bagian tanaman yang diinginkan (Menteri Pertanian Republik Indonesia, 
2014). Berdasarkan organisme sasarannya, pestisida dapat digolongkan menjadi insektisida, akarisida, moluskisida, rodentisida, nematisida, fungisida, bakterisida, herbisida, algisika, piskisida, avisida, repelen, atraktan, ZPT atau bahan untuk mengatur pertumbuhan tanaman, dan plant activator yang digunakan untuk merangsang kekebalan tumbuhan (Nenotek \& Harini , 2018).

Penggolongan atau klasifikasi pestisida berdasarkan senyawa kimia penyusunnya yaitu, arsen, antimon, barium, boron, tembaga, fluorin, merkuri, selenium, talium, seng, amonium sulfamat, sulfur, kuprum, merkuri, seng fosfisida, talium sulfat, hidrokarbon berklor, organofosfat, karbamat, formamidin, dan piretroid (Nenotek \& Harini , 2018).

Paparan pestisida pada tubuh dapat menyebabkan keracunan pestisida. Keracunan ringan dapat menimbulkan gejala berupa iritasi pada hidung, tenggorokan, mata, atau kulit, pusing, sakit kepala, penurunan nafsu makan, rasa haus, mual, diare, berkeringat, kelelahan dan kelemahan, perubahan mood, dan insomnia. Keracunan sedang dapat menimbulkan gejala berupa muntah, salivasi berlebih, batuk, adanya perasaan konstriksi pada tenggorokan dan dada, kram perut, pandangan kabur, kelelahan, dan merasa kebingungan. Keracunan pestisida berat dapat menyebabkan kesusahan bernapas, pupil pinpoint, produksi mukus yang berlebihan pada sistem pernapasan, napas cepat, luka bakar kimia pada kulit, penurunan refleks, penurunan kesadaran, dan bahkan kematian (Canadian Centre for Occupational Health and Safety, 2017). Selain itu, pestisida seperti golongan organofosfat, organoklorin, karbamat, dan golongan lainnya juga diketahui merupakan endocrine disruptor chemical (EDC) atau pengganggu sistem endokrin. EDC melakukan inhibisi terhadap reseptor hormon estrogen, androgen, dan hormon lainnya sehingga hormon-hormon tersebut tidak dapat bekerja. Salah satu hormon yang dipengaruhi oleh EDC ini adalah hormon tiroid. Inhibisi hormon tiroid oleh berbagai golongan pestisida ini dapat menyebabkan kondisi hipotiroid bagi individu yang terkena paparannya (Mnif et al, 2011). Hal ini sejalan dengan penelitian oleh Bantarwati el al., bahwa paparan pestisida memiliki efek terhadap penurunan hormon tiroid pada wanita di lingkungan agrikultur (Bantarwati, Suhartono, \& Suwondo, 2013). Goldner et al., juga menyebutkan bahwa organoklorin merupakan salah satu penyebab dari kejadian hipotiroid pada wanita di lingkungan agrikultur (Goldner et al, 2009). Hal ini juga selaras dengan penelitian oleh Rathore, et al., yang juga menyebutkan adanya hubungan antara organoklorin terhadap kejadian hipotiroid (Rathore et al, 2002).

Hipotiroid merupakan keadaan dimana terjadi kekurangan hormon tiroid dalam tubuh. Hormon tiroid yang terdiri atas T3 dan T4 diproduksi oleh kelenjar tiroid. Produksi hormon tiroid distimulasi oleh thyroid stimulationg hormone (TSH) yang diproduksi oleh kelenjar hipofisis anterior. Keadaan hipotiroid ditandai dengan meningkatnya kadar TSH dan menurunnya kadar T4 bebas. Hormon tiroid memiliki pengaruh terhadap metabolisme karbohidrat, protein, lemak, dan vitamin sehingga tubuh dapat menggunakan energi dari hasil metabolisme zat-zat tersebut. Hormon ini juga dibutuhkan untuk maturasi dan diferensiasi sel dengan baik. Hormon tiroid bersama dengan hormon pertumbuhan (growth hormone atau GH) membantu regulasi pertumbuhan tulang, sintesa berbagai protein serta maturasi jaringan saraf termasuk otak. Pengaruh hormon tiroid yang lain yaitu meningkatkan kepekaan tubuh terhadap katekolamin dalam bentuk epinefrin dan norepinefrin yang juga berpengaruh terhadap neurotransmiter pada otak. Apabila kadar hormon tiroid rendah dalam darah atau terjadi hipotiroidisme, maka terdapat gangguan metabolisme, pertumbuhan, dan diferensiasi sel, maturasi sel saraf dalam otak, dan gangguan regulasi neurotransmiter di dalam otak (Rudijanto, 2015).

Roman, 2007 menyebutkan bahwa adanya zat kimia seperti pestisida yang memiliki efek EDC atau memiliki sifat antitiroid juga merupakan faktor yang menyebabkan autisme. Beberapa jenis pestisida yang memiliki efek EDC antara lain 2,4-dichlorophenoxyacetic acid (2,4-D), mancozeb, acetochlor, aminotriazole, aminotrole, bromoxynil, pendamethalin, dan 
thiourea. Bahan-bahan dapat berkompetisi dengan reseptor hormon tiroid sehingga menyebabkan hormon tiroid tidak dapat berikatan dengan reseptor atau kerja hormon tiroid dapat terinhibisi dan terjadilah kondisi hipotiroid. Penurunan kadar tiroid dapat menurunkan kemampuan dari pertumbuhan dari dendrit pada sel purkinje di cerebellum yang diperantarai oleh hormon tiroid. Hal tersebut dapat mempengaruhi neuroanatomi dan neurokemistri berupa neurotransmitter pada otak sehingga dapat menyebabkan kondisi autisme (Roman, 2007).

Autisme merupakan suatu kondisi yang ditandai dengan gangguan pada interaksi sosial, komunikasi, bahasa, keterbatasan minat, dan aktivitas yang dilakukan berulang-ulang (World Health Organization, 2018). Gangguan-gangguan tersebut biasanya muncul sebelum usia 3 tahun (Rudijanto, 2015). Kejadian autisme di dunia berdasarkan CDC tahun 2019 yaitu sebanyak 1 dari 59 anak di dunia teridentifikasi terkena autisme atau autism spectrum disorder (ASD). Autisme 4 kali lebih banyak terjadi pada anak laki-laki dibandingkan dengan anak perempuan. Autisme dapat terjadi pada semua etnis, ras, dan berbagai tingkatan sosioekonomi (Center for Disease Control and Prevention, 2019).

Gangguan pada kemampuan interaksi dan komunikasi sosial pada anak dengan autisme ditandai dengan kurangnya minat pada sesuatu yang menjadi perhatian orang lain, kegagalan dalam komuninkasi sosial, kurangnya minat pada suatu hal yang mungkin menjadi minat pada kebanyakan anak seusianya. Selain itu juga terdapat gangguan timbal balik sosial dan emosional, serta anak tidak mampu bermain imitatif atau pura-pura, misalnya dengan boneka atau dengan mainan lainnya. Gangguan komunikasi yang mungkin muncul yaitu keterlambatan berbicara, gangguan untuk memulai atau mempertahankan percakapan, kegagalan dalam pengalihan topik pembicaraan, sulit menanyakan informasi, atau tidak merespon pembicaraan orang lain. Anak dengan autisme juga memiliki bahasa yang berbeda dengan anak seusianya. Bahasa yang digunakan pada anak autisme biasanya berupa bahasa yang stereotipikal, repetitif, atau idiosinkratik. Anak dengan autisme juga sering melakukan repetisi pada kata-kata yang diucapkan lawan bicaranya atau disebut dengan ekolalia. Selain itu juga terdapat respon yang tidak wajar saat merespon pembicaraan, misalnya respon yang terlalu monoton, volume yang rendah atau bahkan respon menyentak dan volume serta suara yang tinggi (Widyawati \& Kaligis, 2017; National Autism Association, 2018; Center for Disease Control and Prevention, 2019; National Institute of Neurological Disorders and Stroke, 2019).

Anak dengan autisme juga dapat mengalami gangguan pada aktivitas sensorik dan motorik yang repetitif, dan keterbatasan minat atau kelebihan minat pada suatu hal tertentu. Anak dengan autisme memiliki rutinitas yang sama setiap harinya, serta kesulitan untuk beralih dari rutinitas tersebut walaupun hanya dalam skala yang kecil. Jika terdapat perubahan pada rutinitas tersebut, maka dapat mengakibatkan permasalahan yang besar dalam kehidupan sehari-hari serta dapat menyebabkan gejala tantrum atau dapat juga kegelisahan yang berat. Selain itu juga terdapat aktivitas motorik yang repetitif yang sering dilakukan oleh anak dengan autisme, seperti menggoyangkan tangan, menyusun balok, menjetikkan jadi, dan sebagainya. Pada anak dengan autisme, selain adanya aktivitas motorik yang repetitif, anak juga sering mengalami kesulitan dalam melakukan aktivitas koordinasi motorik seperti menyikat gigi, mengikat tali sepatu, mengancingkan baju, dan sebagainya(Widyawati \& Kaligis, 2017; National Autism Association, 2018; Center for Disease Control and Prevention, 2019; National Institute of Neurological Disorders and Stroke, 2019; National Health Service, 2019).

Anak dengan autisme juga dapat mengalami gangguan kognitif yang dapat berupa retardasi mental dengan derajat sedang. Terdapat juga gangguan tidur, berupa pola tidur keterbalikan dan sering terbangun pada malam hari. Terdapat juga gangguan makan berupa tidak mau untuk mengkonsumsi makanan tertentu, hanya suka pada jenis makanan tertentu, dan tidak suka mencoba makanan baru, serta dapat terjadi pica eating atau memakan benda- 
benda yang bukan bahan makanan, seperti tanah, kertas, dan sebagainya). Anak dengan autisme juga dapat mengalami gangguan mood dan afek, yang dapat berupa perubahan mood secara tiba-tiba, misalnya tiba-tiba tertawa sendiri atau tiba-tiba menangis, atau mudah menjadi emosional, dan takut pada objek yang tidak menakutkan, serta kecemasan yang berat saat berpisah dengan orang tua. Terdapat perilaku yang membahayakan yang dapat dilakukan oleh anak dengan autisme, seperti menggigit tangan sendiri, membentur-benturkan kepala, memukul diri sendiri, atau secara agresif melawan orang lain. Pada anak dengan autisme juga dapat terjadi kejang epilepsi pada 10-25\% anak (Widyawati \& Kaligis, 2017; National Autism Association, 2018; Center for Disease Control and Prevention, 2019).

Terdapat beberapa teori mengenai faktor-faktor risiko yang dapat menyebabkan timbulnya autisme, diantaranya adalah teori biologis, teori imunologi, dan adanya infeksi virus. Teori biologis yang berperan terhadap kejadian autisme diantaranya adalah adanya faktor genetik, faktor peri-natal, model neuroanatomi, dan hipotesis neurokemistri. Berdasarkan faktor genetik, anak kembar satu telur berisiko sebesar 36-89\% untuk keduanya terjadi autisme, sedangkan pada saudara kandung yang mengalami autisme sebelumnya, terdapat risiko 50-100\% untuk terjadi autisme pada kelahiran berikutnya. Adanya gangguan kromosom berupa sindrome fragile-X juga merupakan faktor genetik yang berisiko menyebabkan autisme(Widyawati \& Kaligis, 2017).

Adanya komplikasi pre-natal, peri-natal dan neo-natal juga menjadi penyebab kejadian autisme. Komplikasi tersebut di antaranya, adalah perdarahan setelah trimester pertama, adanya kotoran janin pada cairan amnion, riwayat konsumsi obat-obatan ibu selama hamil, dan adanya komplikasi saat persalinan, diantaranya gangguan pernafasan, bayi terlambat menangis, dan anemia pada janin. Berdasarkan teori faktor neuroanatomi, adanya lesi di otak juga menyebabkan timbulnya autisme. Beberapa jenis neurotransmiter juga diduga menjadi salah satu penyebab terjadinya autisme, seperti peningkatan kadar serotonin, gangguan kadar dopamin, dan opioid. Berdasarkan teori imunologi, adanya antigen leukosit pada anak, terutama yang ada di otak, menyebabkan adanya antibodi ibu menyerang antigen tersebut sehingga dapat merusak jaringan saraf pada otak janin dan dapat berkembang menjadi autisme. Selain itu, beberapa infeksi virus kongenital, seperti infeksi rubella, herpes simpleks, ensefalitis, dan infeksi Cytomegalovirus (CMV) juga diduga menjadi penyebab terjadinya autisme (Widyawati \& Kaligis, 2017).

Berdasarkan Lyall et al., terdapat faktor eksternal yang juga berpengaruh terhadap kejadian autisme, yaitu adanya paparan tinggi pestisida pada ibu hamil (Lyall et al, 2017). Penelitian Schmidt, et al., juga menyebutkan bahwa adanya paparan pestisida dan disertai dengan rendahnya konsumsi asam folat juga berpengaruh terhadap kejadian autisme (Schmidt, 2017). Penelitian Brown et al., juga mendukung bahwa paparan pestisida berpengaruh pada kejadian autisme (Brown, 2018).

Berdasarkan uraian tersebut, dapat diketahui bahwa paparan pestisida yang terjadi terus menerus pada ibu hamil dapat menyebabkan adanya inhibisi pada hormon tiroid sehingga terjadilah kondisi hipotiroid. Kondisi ini dapat menyebabkan gangguan pada neurotransmitter otak sehingga hal tersebut sejalan dengan teori model neuroanatomi dan teori hipotesis neurokemistri yang menjadi penyebab terjadinya autisme(Widyawati \& Kaligis, 2017). Mengingat tingginya risiko bahaya dari penggunaan pestisida, perlu dilakukan pelatihan mengenai penggunaan pestisida secara tepat dan risiko penggunaanya. Salah satu metode yang efektif dalam meningkatkan aksi masyarakat dalam penggunaan pestisida secara waspada terkhususnya ibu-ibu yang sedang hamil adalah dengan meningkatkan perilaku melalui pelatihan yang dilakukan oleh pelayanan kesehatan. (Gunawan et al, 2018). Secara umum pelayanan kesehatan masyarakat merupakan sub sistem pelayanan kesehatan yang tujuan utamanya adalah pelayanan preventif (pencegahan) dan promotif (peningkatan kesehatan) dengan sasaran masyarakat (Sulaiman \& Anggriani, 2018). 


\section{Kesimpulan}

Pestisida memiliki efek endocrine disruptor chemical (EDC) atau pengganggu sistem endokrin. Endocrine disruptor chemical melakukan inhibisi terhadap reseptor tiroid. Inhibisi hormon tiroid oleh berbagai golongan pestisida ini dapat menyebabkan kondisi hipotiroid bagi individu yang terkena paparannya, termasuk pada ibu hamil. Penurunan kadar tiroid dapat menurunkan kemampuan dari pertumbuhan dari dendrit pada sel purkinje di cerebellum yang diperantarai oleh hormon tiroid. Hal tersebut dapat mempengaruhi neuroanatomi dan neurokemistri berupa neurotransmitter pada otak sehingga dapat menyebabkan kondisi autisme pada bayi yang dilahirkan.

\section{Rerefensi}

Costa L.G. (2008). Toxic effects of pesticides. In: L.J. Casarett \& J. Doull, eds. 2008. Toxicology. The basic science of poisons. 7th ed. New York: Macmillan Publishing Company.

Bambang S, Onny S, Nur E. (2013). Hubungan paparan pestisida pada masa kehamilan dengan kejadian berat badan bayi lahir rendah (BBLR) di kecamatan ngablak kabupaten magelang. Jurnal Kesehatan Lingkungan Indonesia Vol. 12(1), 26-33.

Bretveld WR, Thomas CMG, Scheepers PTJ, Zielhuis GA, Roeleveld N. (2006). Pesticide exposure: the hormonal function of the female reproductive system disrupted. BioMedCentral : Reproductive Biology and Endrocrinology Vol. 4(30).

Whyatt RM, et al. (2004). Prenatal insecticide exposure and birth weight and length among urban minority cohort. Environmental Health Perspectives.

Menteri Pertanian Republik Indonesia. (2014). Peraturan menteri pertanian republik indonesia nomor 107 tahun 2014 tentang pengawasan pestisida. Jakarta : Sekretariat Negara.

Nenotek P, Harini T. (2018) .Buku ajar pestisida dan teknik aplikasi. Kupang : PTK Press.

Canadian Centre for Occupational Health and Safety. (2017).Pesticides-health effects.OSH Answers Fact Sheets.

Mnif W, Hassine A, Bouaziz A, Bartegi A, Thomas O, Roig B. (2011). Effect of endocrine disruptor pesticides: a review. Int. J. Environ. Res. Public Health Vol 8, 2265-2303.

Bantarwati D, Suhartono, Suwondo A. (2013). Hubungan pajanan pestisida dengan kejadian hipotiroid pada wanita usia subur di daerah pertanian hortikultura desa gombong kecamatan belik pemalang. Jurnal Kesehatan Lingkungan Indonesia Vol 12 (2), 138-143.

Goldner W, et al. (2009). Pesticide use and thyroid disease among women in the agricultural health study. American Journal of Epidemiology Vol 171(4), 455-464.

Rathore M, Bhatnagar P, Mathur D, Saxena G. (2002). Burden of organochlorine pesticides in blood and its effect on thyroid hormones in women. Elsevier (295), 207-215.

Rudijanto A. (2015). Buku ajar ilmu penyakit dalam : hipotiroid. Jakarta : Interna Pusblishing.

Roman G. (2007). Autism : transient in utero hyphothyroxinemia related to maternal flavonoid ingestion during pregnancy and to other environmental antithyroid agents. Elsevier $262: 15-26$.

World Health Organization. (2018).Autism spectrum disorders. Fact Sheets WHO.

Center for Disease Control and Prevention. (2019). Data \& statistics on autism spectrum disorder. National Center on Birth Defects and Developmental Disabilities.

Widyawati I, Kaligis F. (2017). Buku ajar psikiatri : gangguan spectrum autism. Jakarta : Fakultas Kedokteran Universitas Indonesia. 494 p.

National Autism Association. (2018). Signs of autism. About Autism. 
Center for Disease Control and Prevention. (2019). Signs and symptoms of autism spectrum disorders. National Center on Birth Defects and Developmental Disabilities.

National Institute of Neurological Disorders and Stroke. (2019). Autism spectrum disorder fact sheet. Patient \& Caregiver Education.

National Health Service. (2019).Signs of autism in children. Health A to Z, Autism.

Lyall K, et al. (2017). Polychlorinated biphenyl and organochlorine pesticide concentrations in maternal mid-pregnancy serum samples: association with autism spectrum disorder and intellectual disability. Environmental Health Perspective Vol 125(3): 474-480.

Schmidt, R. (2017). Combined prenatal pesticide exposure and folic acid intake in relation to autism spectrum disorder. Environmental Health Perspectives.

Brown A. (2018). Maternal insecticide levels are associated with autism in offspring from a national birth cohort. Am J Psychiatry Vol 175(11): 1094-1101.

Gunawan R, Pratama M, Sulaiman, Anggriani, Gurning F. (2018). Increasing Of HIV / AIDS Prevention And Drugs Through Whatsapp Based Training And Assistance In Adolescents In Batang Kuis Deli Serdang District. International Journal of Scientific and Engineering research. Vol. 9(9).

Sulaiman, \& Anggriani. 2019. Hubungan Mutu Pelayanan Terhadap Kepuasan Pasien di Poli Fisioterapi RSU Siti Hajar. Jurnal Endurance: Kajian Ilmiah Problema Kesehatan, 4(2), 252-261. 